IRA-International Journal of Applied Sciences ISSN 2455-4499; Vol.07, Issue 01 (2017)

Institute of Research Advances

Pg. no. 42-51

https://research-advances.org/index.php/IRAJAS

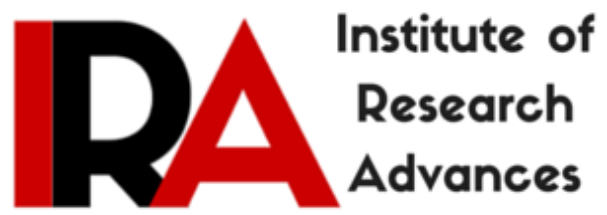

\title{
Biomass- An Overview on Composition Characteristics and Properties
}

\author{
Kavita Parmar \\ Centre for Environmental Sciences, Central University of Jharkhand, \\ Brambe, Ranchi, India.
}

Type of Review: Peer Reviewed.

DOI: http://dx.doi.org/10.21013/jas.v7.n1.p4

\section{How to cite this paper:}

Parmar, K. (2017). Biomass- An Overview on Composition Characteristics and Properties. IRAInternational Journal of Applied Sciences (ISSN 2455-4499), 7(1), 42-51.

doi:http://dx.doi.org/10.21013/jas.v7.n1.p4

(C) Institute of Research Advances

\section{(c) E) EY-NC}

This work is licensed under a Creative Commons Attribution-Non Commercial 4.0 International License subject to proper citation to the publication source of the work.

Disclaimer: The scholarly papers as reviewed and published by the Institute of Research Advances (IRA) are the views and opinions of their respective authors and are not the views or opinions of the IRA. The IRA disclaims of any harm or loss caused due to the published content to any party. 


\begin{abstract}
A general overview has been proposed for biomass composition, characteristics and property. Biomass is the combination of all organic materials that simplify referring to amount of animal and plant. Biomass materials are diverse, ranging from wood, bark, straw and other agricultural residues, grasses and offspec grains. Despite of diversity the composition of most biomass materials is relatively uniform, when moisture has been excluded. Biomass burning emission is an important part of carbon and nitrogen cycle. The pollutants released by biomass burning varies depends upon the constituents of nitrogen sulphur and carbon. In this paper basic knowledge of biomass and comparative data regarding composition and characterization has been studied.
\end{abstract}

Keywords: Biomass, Categorization, Composition, Property.

\title{
Introduction
}

Biomass consists of bio + mass that simply referring to amount of animal and plant. It refers to the organic matter deriving from plants and that is generated through photosynthesis.

Biomass is combination of all organic material that stems from plants (including algae, plant, trees and crops). It is produced by green plants converting sunlight into plant material through photosynthesis and includes all land and water based vegetation, as well as all organic wastes (Kendry 2002). When burned, the energy stored in biomass is released to produce heat or electricity. Common forms of solid biomass include agricultural crops, crop residue and forestry products (Jenkins., et.al.1998).

For Plant material the carbon used to construct biomass is absorbed from the atmosphere as carbon dioxide $\left(\mathrm{CO}_{2}\right)$ by plant life, using energy from the sun. Plants may subsequently be eaten by animals and thus converted into animal biomass. However the primary absorption is performed by plants.

If plant material is not eaten it is generally either broken down by micro-organisms or burned: If broken down it releases the carbon back to the atmosphere, mainly as either carbon dioxide $\left(\mathrm{CO}_{2}\right)$ or methane $\left(\mathrm{CH}_{4}\right)$, depending upon the conditions and processes involved. If burned the carbon is returned to the atmosphere as $\mathrm{CO}_{2}$.

These processes have happened for as long as there have been plants on Earth and is part of what is known as the carbon cycle.

From the perspective of energy resources, a common definition is "a general term for animal and plant resources and the wastes arising from them, which have accumulated in a certain amount (excluding fossil resources)."

- Biomass is an abundant and renewable source of energy.

- Using biomass for energy would diversify the energy supply and reduce dependency on fossil fuels.

In this paper i have tried to discuss about basic knowledge of biomass, its origination, availability, categories of bioresources and property of biomass. From the entire study also discussed about the ultimate analysis of biomass. This paper will be helpful in our next study related to study of emission from biomass burning.

\section{Origination of biomass}

Carbon dioxide $\left(\mathrm{CO}_{2}\right)$ from the atmosphere and water absorbed by the plant roots are combined in the photosynthetic process to produce carbohydrates (or sugars) that form the biomass. Or Biomass is the 
plant material derived from the reaction between Carbon dioxide $\left(\mathrm{CO}_{2}\right)$ in the air, water and sunlight, via photosynthesis to produce carbohydrate that forms the building blocks of biomass (Kendry 2002).

The solar energy that drives photosynthesis is stored in the chemical bonds of the biomass structural components. During biomass combustion, oxygen from the atmosphere combines with the carbon in biomass to produce $\mathrm{CO}_{2}$ and water. The process is therefore cyclic because the carbon dioxide is then available to produce new biomass. This is also the reason why bio-energy is potentially considered as carbon-neutral, although some $\mathrm{CO}_{2}$ emissions occur due to the use of fossil fuels during the production and transport of biofuels (Broek et.al., 1996).

\section{Availability of bio resources}

The earth has a huge stock biomass covering wide regions including forests and the ocean. The total biomass of the world is 1,800 billion tons on the ground and 4 billion tons in the ocean, and a comparative amount of biomass exists in the soil. The total biomass on the ground is 33,000 EJ on the energy basis, which corresponds to 80 times or more of the annual energy consumption of the world (Stegmann, 1996).

However some part of the biomass is used as food by living things including humans, and also for uses other than foods which are necessary for the human living.

\section{Categories of Biomass resources}

There is no established way of categorizing biomass, which is defined differently according to the field; categorization changes depending on the purpose and application. Generally there are two ways to categorize biomass: one is biological categorization based on types of existing biomass in nature and the other is based on the use or application as resources.

An example of biomass categorization appears in figure 1(Yokoyama, 2008). In this categorization, biomass includes not only the conventional product and waste from agriculture, forestry and fisheries, but also plantation biomass.

\section{Conventional Biomass Resources \\ Agriculture, Forestry(woody), Fishery, Livestock farming Food, Materials, Medicine, Timber, Pulp, Chip etc.}

Biomass wastes (Derivatives)

Agricultural, Forestry, Fishery, Livestock residues(wastes) Rice straw, Cattle manure, Lumber mill, saw dust, sewage sludge, Black liquor

Plantation Biomass

Forestry- Eucalyptus, Poplar, Willow, Oil palm

Herbaceous- Sugarcane, Switchgram, Sorghum, Corn

Aquatic- Giant Kelp, Water hyacinth, Algae

Fig.1. Biomass Categorization (in terms of use and application), Source: Yokoyama, 2008; 
According to the different sectors biomass resources can be classified differently has been shown in Table 1 (www.ieabcc.nl).

Table 1. Biomass classification on the basis of different sector, Source: (www.ieabcc.nl).

\begin{tabular}{|c|c|c|}
\hline Sectors & Type & Examples \\
\hline \multirow[t]{2}{*}{ Forestry } & Dedicated forestry & Short rotation plantations (e.g. willow, poplar, eucalyptus) \\
\hline & Forestry by-products & Wood blocks, wood chips from thinnings \\
\hline \multirow[t]{6}{*}{ Agriculture } & $\begin{array}{l}\text { Dry lignocellulosic } \\
\text { energy crops }\end{array}$ & $\begin{array}{l}\text { Herbaceous crops (e.g. miscanthus, reed canarygrass, giant } \\
\text { reed) }\end{array}$ \\
\hline & \multirow{3}{*}{$\begin{array}{l}\text { Oil, sugar and starch } \\
\text { energy crops }\end{array}$} & Oil seeds for methylesters (e.g. rape seed, sunflower) \\
\hline & & Sugar crops for ethanol (e.g. sugar cane, sweet sorghum) \\
\hline & & Starch crops for ethanol (e.g. maize, wheat) \\
\hline & Agricultural residues & Straw, prunings from vineyards and fruit trees \\
\hline & Livestock waste & Wet and dry manure \\
\hline \multirow[t]{2}{*}{ Industry } & \multirow{2}{*}{ Industrial residues } & Industrial waste wood, sawdust from sawmills \\
\hline & & Fibrous vegetable waste from paper industries \\
\hline \multirow[t]{5}{*}{ Waste } & Dry lignocellulosic & Residues from parks and gardens (e.g. prunings, grass) \\
\hline & \multirow{4}{*}{ Contaminated waste } & Demolition wood \\
\hline & & Organic fraction of municipal solid waste \\
\hline & & Biodegradable landfilled waste, landfill gas \\
\hline & & Sewage sludge \\
\hline
\end{tabular}

Biomass fuels consist of three main segments: wood, waste and alcohol fuels and the hierarchy of biomass energy resources has been shown in figure 2 (Energy Information Administration/Estimates of U.S.Biomass Energy Consumption 1992). 


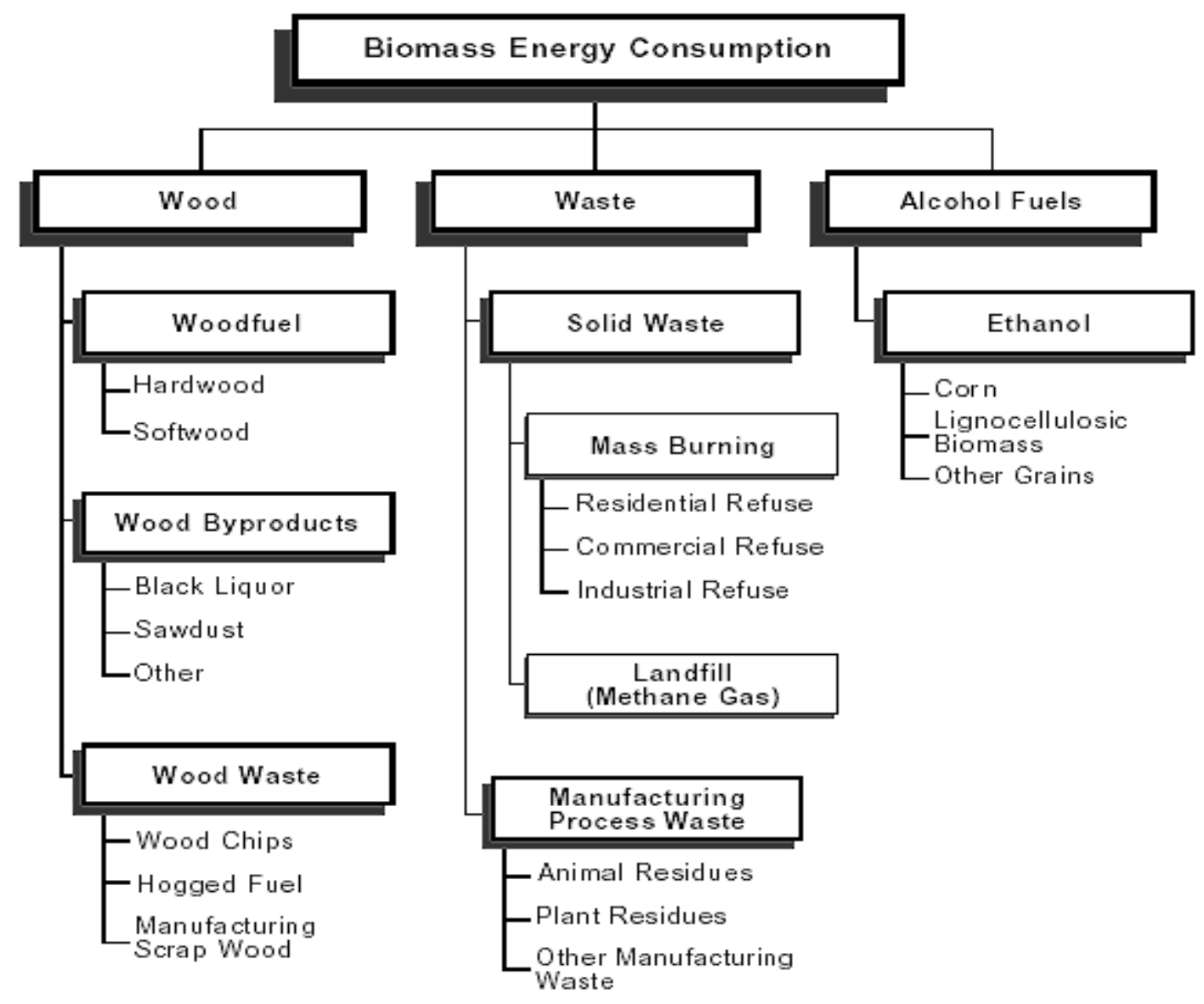

Figure 2. Biomass Energy Resource Hierarchy, Source: Energy Information Administration/Estimates of U.S.Biomass Energy Consumption 1992.

\section{Biomass composition}

There is a wide variety of biomass, and composition varies significantly. Some primary components are cellulose, hemicelluloses, lignin, starch and proteins. Trees mainly consist of cellulose, hemicelluloses and lignin(Yokoyama, 2008).

a) Cellulose- $\quad$ A polysaccharide in which D-glucose is linked uniformly by $\beta$-glucosidic bonds. Its molecular formulae is $\left(\mathrm{C}_{6} \mathrm{H}_{12} \mathrm{O}_{6}\right)_{\mathrm{n}}$. The degree of polymerization, indicated by $\mathrm{n}$, is broad, ranging from several thousand to several ten thousands.

b) Hemi cellulose- A polysaccharide whose units are 5-carbon monosaccharide including D-xylose and D-arabinose and 6-carbon monosaccharide's including D-mannose, Dgalactose and D-glucose.

c) Lignin- A compound whose constituents units, phenylropane and its derivatives are bonded 3-dimensionally, cellulose, hemicelluloses and lignin are universally 
found in many kinds of biomass and are the most plentiful natural carbon resources on earth.

The chemical composition of plant biomass varies among species. In general terms, plants are made of approximately $25 \%$ lignin and $75 \%$ carbohydrates or sugars. The carbohydrate fraction consists of many sugar molecules linked together in long chains or polymers. Two categories are distinguished: cellulose and hemi-cellulose. The lignin fraction consists of non-sugar type molecules that act as a glue holding together the cellulose fibers. Table 2(www.ecn.nl/phyllis) shows typical values of cellulose, hemicellulose and lignin for the composition of straw, softwoods and hardwoods.

Table 2. Typical values for the composition of straw, softwoods and hardwoods, Source: (www.ecn.nl/phyllis).

\begin{tabular}{|l|l|l|l|}
\hline & Cellulose(\%) & Hemi-cellulose(\%) & Lignin(\%) \\
\hline Softwood & 45 & 25 & 30 \\
\hline Hardwood & 42 & 38 & 20 \\
\hline Straw stalks & 40 & 45 & 15 \\
\hline
\end{tabular}

\section{Energy content of biomass}

The heating value of a fuel indicates the energy available in the fuel per unit mass-MJ/kg(BTU/lb). The net heating value is the actual energy available for heat transfer. The difference in available energy is explained by the fuel's chemical composition, moisture and ash content.

\section{Moisture}

Moisture content is the key factor determining the net energy content of biomass material. The most important property of biomass feedstocks with regard to combustion-and to the other thermo-chemical processes-is the moisture content, which influences the energy content of the fuel. Dry biomass has a greater heating value, as it uses little of its energy to evaporate any moisture. There is a correlation between energy and moisture contents. Increased moisture means less energy available. Table 3(www.vt.tuwien.ac.at/biobib) shows possible ranges in moisture content for selected biomass resources and table 4 shows the evolution of the lower heating value (LHV, in GJ/t) of wood as a function of the moisture content.

All biomass materials contain some moisture, from as low as $10 \%$ for dried straw to over $50 \%$ for freshcut wood.

Table 3. Possible ranges in moisture content for selected biomass resources, Source: www.vt.tuwien.ac.at/biobib

\begin{tabular}{|l|l|}
\hline Biomass resources & Moisture content (\%) \\
\hline Industrial fresh wood chips and sawdust & $40-60 \mathrm{wt.} \%(\mathrm{wb})$ \\
\hline Industrial dry wood chips and sawdust & $10-20 \mathrm{wt.} \%(\mathrm{wb})$ \\
\hline Fresh forest wood chips & $40-60 \mathrm{wt.} \%(\mathrm{wb})$ \\
\hline $\begin{array}{l}\text { Chips from wood stored and air-dried several } \\
\text { months }\end{array}$ & $30-40 \mathrm{wt} \%$ (wb) \\
\hline Waste wood & $10-30 \mathrm{wt} \%$ (wb) \\
\hline Dry straw & 15 wt. \% (wb) \\
\hline
\end{tabular}


Table 4. Some typical characteristics of biomass fuels compared to oil and coal,

\begin{tabular}{|l|l|l|l|l|l|}
\hline Typical characteristics & $\mathrm{GJ} / \mathrm{t}$ & toe/t & $\mathrm{Kg} / \mathrm{m}^{3}$ & $\mathrm{GJ} / \mathrm{m}^{3}$ & $\begin{array}{l}\text { Volume oil } \\
\text { equivalent }\left(\mathrm{m}^{3}\right)\end{array}$ \\
\cline { 1 - 5 } Fuel & & & & & \\
\cline { 1 - 5 } Fuel oil & 41.9 & 1,00 & 950 & 39,8 & 1,0 \\
\hline Coal & 25.0 & 0,60 & 1000 & 25,0 & 1,6 \\
\hline Pellets 8\% moist. & 17.5 & 0,42 & 650 & 11,4 & 3,5 \\
\hline Pile wood (stacked, 50\%) & 9.5 & 0,23 & 600 & 5,7 & 7,0 \\
\hline Industrial softwood chips 50\% moist. & 9.5 & 0,23 & 320 & 3,0 & 13,1 \\
\hline Industrial softwood chips 20\% moist. & 15.2 & 0,36 & 210 & 3,2 & 12,5 \\
\hline Forest softwood chips 30\% moist. & 13.3 & 0,32 & 250 & 3,3 & 12,0 \\
\hline Forest hardwood chips 30\% moist. & 13.3 & 0,32 & 320 & 4,3 & 9,3 \\
\hline Straw chopped 15\% moist. & 14.5 & 0,35 & 60 & 0,9 & 45,9 \\
\hline Straw big bales 15\% moist. & 14.5 & 0,35 & 140 & 2,0 & 19,7 \\
\hline Source: & & & & \\
\hline
\end{tabular}

Source: $\underline{w w w . v t . t u w i e n . a c . a t / b i o b i b}$

Ash

The non-combustible content of biomass is referred to as ash. High ash content leads to fouling problems, especially if the ash is high in metal halides (e.g., potassium). Unfortunately, biomass fuels, especially agricultural crops/residues tend to have a high ash with high potassium content. Wood (core, no bark) has less than $1 \%$ ash. Bark can have up to $3 \%$ ash. Agricultural crops have higher ash content, from $3 \%$ and higher (Figure 3).

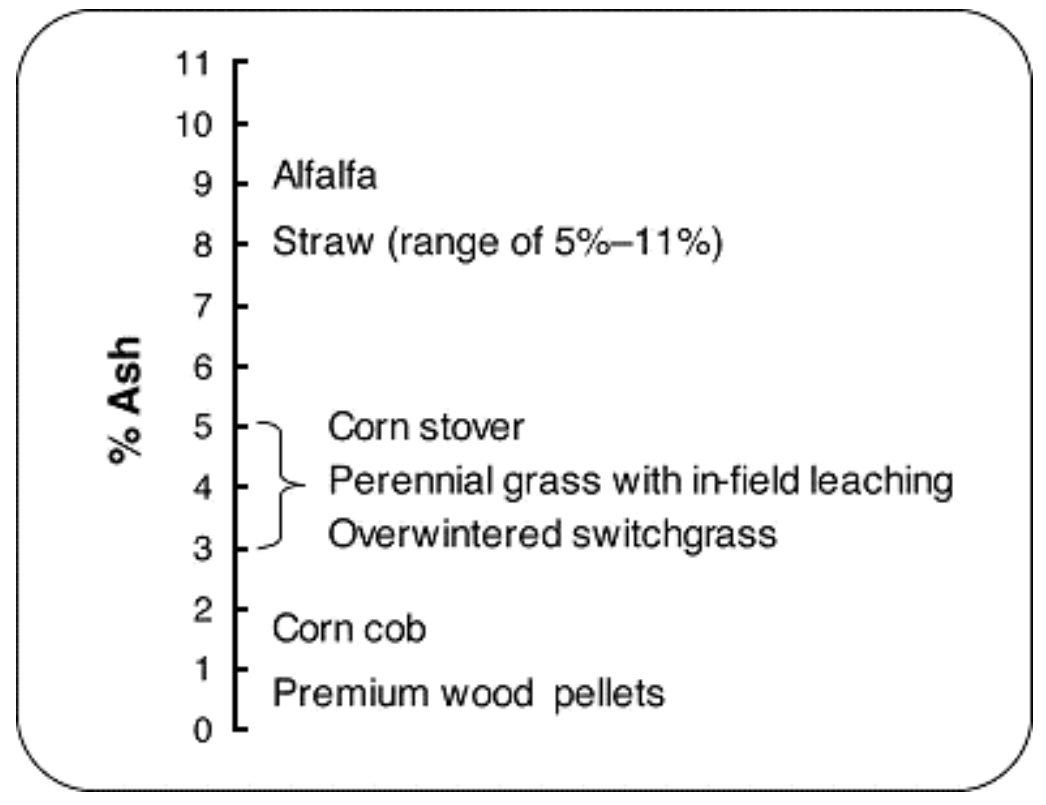

Figure 3. Typical ash content for selected biomass on a dry basis. Source: AURI, 2005; Preto, 2010.

\section{Carbon}

The carbon content of biomass is around $45 \%$, while coal contains $60 \%$ or greater (Demirbas, 2004). A higher carbon content leads to a higher heating value. 


\section{Hydrogen}

The hydrogen content of biomass is around 6\% (Jenkins, 1998). A higher hydrogen content leads to a higher heating value.

\section{Nitrogen}

The nitrogen content of biomass varies from $0.2 \%$ to more than $1 \%$ (Jenkins, 1998). Fuel-bound nitrogen is responsible for most nitrogen oxide (NOx) emissions produced from biomass combustion. Lower nitrogen content in the fuel should lead to lower NOx emissions.

\section{Sulphur}

Most biomass fuels have a sulphur content below $0.2 \%$, with a few exceptions as high as $0.5 \%-0.7 \%$. Coals range from $0.5 \%-7.5 \%$ (Demirbas 2004). Sulphur oxides (SOx) are formed during combustion and contribute significantly to particulate matter (PM) pollution and acid rain. Since biomass has negligible sulphur content, its combustion does not contribute significantly to sulphur emissions.

\section{Chloride}

Combustion of biomass with high chloride concentrations (over $1,000 \mu \mathrm{g} / \mathrm{g}$ ) can lead to increased ash fouling. High chloride content leads to the formation of hydrochloric acid in the boiler tubes, resulting in corrosion that can lead to tube failure and water leaks in the boiler. Fuels where this has been observed include corn stover and corn cobs.

\section{Properties of Biomass}

The ultimate analyses for a variety of biomass materials are presented in Table 5(Auri,2005; Preto, 2010). All results are displayed on a dry matter basis for comparison. By this table we can compare the $\%$ values of ash, carbon, hydrogen, nitrogen, sulphur, oxygen and total chlorine for different biomass.

Table 5. Ultimate analysis for a variety of biomass fuels in Ontario (all values reported on a dry matter basis), Source: AURI, 2005; Preto, 2010.

\begin{tabular}{|c|c|c|c|c|c|c|c|c|c|}
\hline \multirow{3}{*}{ Biomass Type } & \multirow{3}{*}{$\mathrm{MJ} / \mathrm{kg}$} & \multirow{3}{*}{ BTU/lb } & \multicolumn{7}{|c|}{ Typical Values ${ }^{1}$} \\
\hline & & & Ash & Carbon & Hydrogen & Nitrogen & Sulphur & Oxygen & Total \\
\hline & & & $\%$ & $\%$ & $\%$ & $\%$ & $\%$ & $\%^{2}$ & $\begin{array}{l}\text { Chlorine } \\
(\mu \mathrm{g} / \mathrm{g})^{3}\end{array}$ \\
\hline \multicolumn{10}{|c|}{ Off-spec (non-food) grains } \\
\hline Beans & 19 & 7,996 & 4.7 & 45.7 & 6.3 & 4.3 & 0.7 & 38.8 & 193 \\
\hline Corn & 17 & 7,350 & 1.5 & 42.1 & 6.5 & 1.2 & 0.1 & 48.9 & 472 \\
\hline Canola & 28 & 12,220 & 4.5 & 60.8 & 8.3 & 4.5 & 0.5 & 21.4 & 163 \\
\hline Dried distillers grain & 22 & 9,450 & 4.9 & 50.4 & 6.7 & 4.7 & 0.7 & 32.6 & 1,367 \\
\hline \multicolumn{10}{|l|}{ Grass/forages } \\
\hline Big blue stem & 19 & 8,020 & 6.1 & 44.4 & 6.1 & 0.8 & 0.1 & 42.6 & 1,880 \\
\hline Miscanthus & 19 & 8,250 & 2.7 & 47.9 & 5.8 & 0.5 & 0.1 & 43.0 & 1,048 \\
\hline Sorghum & 17 & 7,240 & 6.6 & 45.8 & 5.3 & 1.0 & 0.1 & 42.3 & 760 \\
\hline Switchgrass & 18 & 7,929 & 5.7 & 45.5 & 6.1 & 0.9 & 0.1 & 41.7 & 1,980 \\
\hline \multicolumn{10}{|l|}{ Straw/residue } \\
\hline Alfalfa & 17 & 7,435 & 9.1 & 45.9 & 5.2 & 2.5 & 0.2 & 39.5 & 3,129 \\
\hline Barley straw & 17 & 7,480 & 5.9 & 46.9 & 5.3 & 0.7 & 0.1 & 41.0 & 1,040 \\
\hline Corn cobs & 18 & 7,927 & 1.5 & 48.1 & 6.0 & 0.4 & 0.1 & 44.0 & 2,907 \\
\hline
\end{tabular}




\begin{tabular}{|c|c|c|c|c|c|c|c|c|c|}
\hline Corn stover & 19 & 7,960 & 5.1 & 43.7 & 6.1 & 0.5 & 0.1 & 44.6 & 1,380 \\
\hline Flax straw & 18 & 7,810 & 3.7 & 48.2 & 5.6 & 0.9 & 0.1 & 41.6 & 2,594 \\
\hline Wheat straw & 18 & 7,710 & 7.7 & 43.4 & 6.0 & 0.8 & 0.1 & 44.5 & 525 \\
\hline \multicolumn{10}{|l|}{ Processing by-product } \\
\hline Oat hulls & 19 & 7,960 & 5.1 & 46.7 & 6.1 & 0.9 & 0.1 & 41.1 & 1,065 \\
\hline Soybean hulls & 18 & 7,720 & 4.3 & 43.2 & 6.2 & 1.8 & 0.2 & 44.3 & 266 \\
\hline Sunflower hulls & 20 & 8,530 & 4.0 & 47.5 & 6.2 & 1.0 & 0.2 & 41.2 & 3,034 \\
\hline \multicolumn{10}{|l|}{ Wood } \\
\hline Bark & 19 & 8,432 & 1.5 & 47.8 & 5.9 & 0.4 & 0.1 & 45.4 & 257 \\
\hline Willow & 19 & 8,550 & 2.1 & 50.1 & 5.8 & 0.5 & 0.1 & 41.4 & 134 \\
\hline Hardwood & 19 & 8,300 & 0.4 & 48.3 & 6.0 & 0.2 & 0.0 & 45.1 & 472 \\
\hline \multicolumn{10}{|l|}{ Coal } \\
\hline $\begin{array}{l}\text { Low sulphur subbit coal } \\
-\mathrm{PRB}^{4}\end{array}$ & 25 & 10,520 & 6.0 & 55.0 & 3.7 & 0.9 & 0.4 & 11.5 & 35 \\
\hline Lignite & 22 & 9,350 & 22.0 & 58.8 & 4.2 & 0.9 & 0.5 & 13.6 & 25 \\
\hline
\end{tabular}

${ }^{1}$ The content level of ash, chlorine and other elements can be lowered through crop selectivity, growing conditions, plant fractionation, harvest time and harvest method.

${ }^{2}$ Calculated by difference. Percent by difference refers to the difference between two numbers as a percent of one of them. For example, the percentage difference from 5 to 3 is: $2 / 5=0.4=40 \%$.

${ }^{3}$ A microgram $(\mu \mathrm{g})$ is a unit of mass equal to 1/1,000,000 of a gram (1 x 10-6), or 1/1,000 of a milligram. It is one of the smallest units of mass commonly used.

${ }^{4}$ PRB - Power River Basin

It is important to note that biomass materials naturally contain variability, which depends on:

- geographical location

- variety

- climate conditions

- harvest methods

\section{Summary}

Biomass is combination of all organic materials. The process of bimass derivation to exhaustment is part of carbon cycle. Biomass is an abundant and renewable source of energy. The origination of biomass is derived from the reaction between carbon dioxide via photosynthesis. On energy basis the total biomass available on ground corresponds to 80 times or more of the annual consumption of the world. Biomass is categorized by different means like depending on use, on the basis of different sectors and on the basis of energy resources.

For most biomass fuels, nitrogen and sulphur levels are quite low, that mean resulting in relatively low SOx and NOx emissions. This type of biomass will have less pollutant generation tendency. The major difference in composition of biomass fuel is ash content. The ash content is maximum for grasses and agricultural residues above 5\% for bark 2-3\% and for traditional biomass fuel wood contains less than $0.5 \%$ ash. Maximum ash content cause significant foulig problems like grasses and agricultural residues. On the basis of this study we will try to give our overview in respect of biomass burning emission and its 
relation with the composition of biomass and different characteristics like ash content, moisture content etc.

\section{Acknowledgement}

Author would like to thank DST, India for the Young Scientist Fellowship during the course of this research.

\section{References}

1. Kendry, Mc P., 2002. Energy production from biomass (part 1): overview of biomass. Bioresource Technology. 83, 37-46.

2. Jenkins, B.M., Baxter, L.L., Miles, T.R.,1998. Combustion properties of biomass. Fuel Processing Technology. 54, 17-46.

3. Broek, V., Faaij, R.A., Wijk, A., 1996. Biomass combustion for power generation. Biomassand Bioenergy. 11(4), 270-281.

4. Stegmann, R., 1996. Landfill gas utilization: An overview in landfilling of waste: Biogas(ed T.H.Christensen, R.Cossu, R.Stegmann), E\&FN SPON.

5. Yokoyama, S., 2008, The Asian Biomass Handbook. A guide for biomass production \& utilization. The Japan Institute of Energy.

6. AURI. 2005. Agricultural renewable solid fuels data. Retrieved from Agricultural Utilization Research Institute Fuels Initiative website.

7. Preto, F., 2010. Properties of the 13 common biomass fuels in Ontario. Natural Resource Canada(NRCan), Ottawa, ON.

8. Demirbas, A., 2004. Combustion characteristics of biomass fuels. Progress Energy Combustion Science. 30, 219-230.

9. Energy information administration/Estimates of U.S.Biomass Energy Consumption 1992.

10. www.ieabcc.nl, www.ecn.nl/phyllis, www.vt.tuwien.ac.at/biobib 